\title{
PENERAPAN STRATEGI DIFERENSIASI MEMILIKI PENGARUH TERHADAP KINERJA PERUSAHAAN
}

\author{
Enong Muiz \\ Sunarta \\ sunartan@yahoo.com
}

\begin{abstract}
Abstrak. Penelitian ini bertujuan untuk mengetahui, menguji dan menganalisis Analisis Pengaruh Strategis Umum terhadap Kinerja Perusahaan pada Usaha Kecil Sepatu di Cipayung Ciputat, Tangerang Selatan. Instrumen yang digunakan untuk menangkap data variabel menggunakan kuesioner untuk mendistribusikan model Skala Likert. Uji validitas dihitung dengan rumus Product Moment and Reliability dihitung oleh Alpha Cronbach. Penelitian ini menggunakan pendekatan kuantitatif, karena menekankan pada pengujian teori melalui pengukuran variabel penelitian dengan angka dan analisis data dengan prosedur statistik. penelitian ini menggunakan jenis penelitian survei. sedangkan penelitian ini dilakukan dengan studi eksplanatif. Penelitian ini bertujuan untuk mengetahui hubungan antara strategi generik dan kinerja perusahaan serta untuk menguji penerapan strategi porter dan menjelaskan pengaruh perbedaan pada kinerja perusahaan.
\end{abstract}

Kata Kunci: Strategi Generik, Kinerja Perusahaan.

\section{PENDAHULUAN}

Sebentar lagi Indonesia akan menghadapi tantangan baru dalam dunia perekonomian, sosial - budaya dan politik - keamanan yang dirangkum dalam 10 pilar agenda kawasan - kawasan se Asia Tenggara yang tergabung dalam ASEAN. Agenda yang digagas ini telah menyepakati beberapa agenda yang merupakan visi dari ASEAN untuk membangun kawasan ekonomi yang terintegrasi lewat Masyarakat Ekonomi Asean (MEA). Ini berarti, dalam beberapa tahun kedepan Indonesia dan Negara - negara ASEAN lainnya akan meleburkan diri menjadi satu kesatuan territorial dan perekonomian. Di mana setiap bangsa didorong dalam kompetisi bebas tanpa ada lagi proteksi nasional. MEA ini sendiri akan membawa banyak manfaat bagi negara - negara yang terintegrasi, seperti; turunnya angka kemiskinan, meningkatnya pertumbuhan investasi, peningkatan produk domestic bruto, mengurangi pengangguran, dan peningkatan angka didunia perdaganagn. (Tempo.co,6 oktober 2014), Benarkah demikian? Dengan di- sepakatinya MEA tersebut, belum tentu bisa lebih baik mengenai perekonomian Indonesia bisa malah sebaliknya yaitu menjadi buruk, karena ini adalah babak baru Indonesia dalam menghadapi persaingan dibidang ekonomi. Kerjasama ekonomi yang seharusnya menjadi landasan untuk masyarakat agar sejahtera. Dampak kebijakan neoliberalismr yang diterapakan sudah sangat menjatuhkan tingkat kesejahteraan rakyat, kini ditambah lagi dengan agenda liberalisasi yang lebih luas dan mendalam melalui MEA. Didala rumusannya MEA mempunyai 4 (empat) pilar yang nantinya akan diberlakukan diseluruh Negara yang tergabung di dalam ASEAN, yakni; 1 pasar tunggal dan basis produksi,2) membangun kawasan ekonomi yang berdaya saing tinggi, 3) membangun kawasan dengan ekonomi yang merata, 4) membangun kawasan dengan integrasi penuh terhadap pereekonomian global. Lantas apakah benar 4 (empat) pilar di atas dapat menyelematkan perekonomian Indonesia dan mengurangi kemiskinan? Seperti halnya Neoliberalismr, MEA bisa 
mendatangkan dampak buruk bagi perekonomian nasional: hancurnya sektor produksi nasional (industry dan pertanian) pengangguran meningkat, meluas praktek upah murah, dan lain sebagainya.karena itu, pemerintah harus benar - benar mempersiapkan diri dalam persaingan atau berpikir ulang sebelum terjerumus dalam perdagangan bebas berskala kawsan ASEAN ini.

Beberapa ancaman dan tantangan dalam agenda MEA yang akan menimbulkan ancaman - ancaman bagi kaum perempuan di Indonesia, antara lain: Pertama, pembangunan pasar tunggal menyebkan adanya aliran bebas barang. Artinya, barang -barang dari berbagai Negara ASEAN lainnya akan bebas keluar masuk kedalam negeri untuk diperjualbelikan. Masalah akan muncul ketika produk-produk lokal tidak bisa bersaing dengan produk produk luar, baik secara kualitas maupun harga. ini akan menyebabkan kehancuran sektor produksi nasional. Baik industri nasional berskala besar maupun kecil (UKM dan industry rumah tangga).

Perlu diketahui bahwa sebagian besar pelaku home industry dan UKM di Indonesia adalah kaum perempuan. kementerian pemberdayaan dan perlindangan perempuan menyebutkan bahwa sebanyak $60 \%$ pelaku UKM di Indonesia adalah perempuan. Tentu dapat dibayangkan bagaimana imbasnya kebijakan ini terhadap perempuan, akan semakin menumpuknya jumlah pengangguran perempuan. Yang kedua, liberalisasi pasar tenaga kerja yang berpotensi menyingkirkan tenaga kerja lokal. Di sini, tenaga kerja Indonesia akan dipaksa bersaing dengan tenaga kerja dari negara - negara ASEAN lainnya. Dalam hal ini, diperlukan sumber daya manusia (SDM) yang terampil dan terdidik untuk siap - siap menghadapi persaingan.

HDI (Human Development Index) menunjukan bahwa SDM Indonesia menempati peringkat ke 6 dibawah negara - negara Asean lainnya, seperti Malaysia, Thiland, Brunei, Philipina, dan Singapore. Sementara itu, dari data Asian Productivity Organization (APO) mencatat, dari setiap 1.000 tenaga kerja Indonesia pada tahun 2012, hanya ada sekitar
4,3\% tenaga kerja yang terampil. jumlah itu kalah jauh dibandingkan denagn Filipina yang mencapai 8,3\% Malaysia 32,6\% dan singapore $34,7 \%$. Satu hal yang digadang - gadangkan pemerintah untuk mengatasi hal ini adalah lewat jalur pendidikan dan pelatihan kerja. Masalahnya, pendidikan Indonesia juga mengalami keterpurukan. Tidak sedikit masyarakat Indonesia yang menghadapi benang kusut dalam menghadapi pendidikan yang sanagat mahal harganya.data kementerian pendidikan dan kebudayaan menyebutkan hingga akhir tahun 2013, masih ada 3,6 juta penduduk Indonesia berusia 15 - 59 tahun yang buta huruf.Angka putus sekolah juga masih sangat tinggi. Anggaran pendidikan Indonesia masih terbilang terendah di dunia: anggaran pendidikan kita masih bersikar 3,41\% dari PDB. Sedangkan negara - negara tetangga seperti Malaysia dan Thailand masing - masing punya anggaran pendidikan sebesar 7,9\% dab 5,0\% dari PDB-nya (Berdikari online, 2014). Sejauh ini, tujuan utama MEA adalah mendirikan pasar dan basis produksi tunggal. Sejumlah tujuan laiinya, adalah menjadikan ASEAN sebagai pasar yang kompetitif dan ekonomis, memiliki perkembangan ekonomi yang setara dan terintegrasi secara utuh dengan perekonomian global mestinya kita paling diuntungkan dengan adanya pasa terbuka. Yang penting dampaknya dari segi investasi, kita berkesempatan menjadi base production region, produk Indonesia perlu sertifikasi agar menembus pasar luar negeri. Langkah ini juga dilakukan untuk menghadapi masyarakat ekonomi ASEAN (MEA)/ MEA 2015. Indonesia merupakan pasar potensial untuk produk luar negeri saat pelaksanaan masyarakat ekonomi ASEAN (MEA) 2015 mengingat jumlah penduduk Indonesia besar. Oleh karena itu persiapan menghadapi masyarakat ekonomi ASEAN / MEA 2015 tetap dilakukan untuk menjaga produk dalam negeri.

Perhimpunan bangsa - bangsa Asia Tenggara (Perbara) atau lebih populer dengan sebutan Association of Sountheast Asian Nations (ASEAN) merupakan sebuah organisasi geopolitik dan ekonomi dari negara - negara di 
kawasan Asia Tenggara, yang didirikan di Bangkok, 8 agustus 1967 berdasarkan deklarasi Bangkok oleh indonesia,Malaysia, Filipina, Singapura, Thailand. Organisasi ini bertujuan untuk meningkatkan pertumbuhan ekonomi, kemajuan sosial,dan pengembangan kebudayaan negara - negara anggotanya, memajukan perdamaian dan stabilitas di tingkat regionalnya, serta meningkatkan kesempatan untuk membahas perbedaan di antara anggotanya dengan damai. ASEAN meliputi wilayah daratan seluas 4.46 juta $\mathrm{km} 2$ atau setara dengan $3 \%$ total luas daratan di Bumi, dan memiliki populasi yang mendekati angka 600 juta orang atau setara dengan $8.8 \%$ total populasi dunia. Luas wilayah laut ASEAN tiga kali lipat dari luas wilayah daratan. Pada tahun 2010,kombinasi nominal GDP ASEAN telah tumbuh hingga 1,8 Triliun Dolar AS. Jika ASEAN adalah sebuah entitas tunggal, maka ASEAN akan duduk sebagai ekonomi terbesar kesembilan setelah Amerika Serikat, Cina, Jepang, Jerman, Perancis, Brazil, Inggris, dan Italia.

Dengan diberlakukannya MEA pada akhir 2015, negara anggota ASEAN akan mengalami aliran bebas barang,jasa,investasi,dan tenaga kerja terdidik dari dank le masing masing negara. Melalaui MEA akan terjadi integrasi yang berupa "free trade area" (area perdagangan bebas), penghilang tarif perdagangan antar negara ASEAN, serta pasar tenaga kerja dan pasar modal yang bebas, yang akan sangat berpengaruh pada partumbuhan dan pembangunan ekonomi tiap negara. Ibarat pisau bermata dua manfaata dari implementasi MEA itu bagi pertumbuhan ekonomi Indonesia tentu tergantumng pada cara menyikapi era,pasar bebas tersebut pertanyaannya, sejauh mana kesiapan dunia usaha di Indonesia dalam menghadapi era MEA 2015? Untuk menghadapi era pasar bebas se-asia Tenggara itu,dunia usaha di tanah air tertentu harus mengambil langkah - langkah strategis agar dapat menghadapi persaingan dengan negara ASEAN lainnya,tak terkecuali sektor koperasi dan usaha kecil menengah (KUKM). sebagai persiapan, pemerintah telah melaksanakan beberapa upaya strategis,salah satunya pembentukan Komite Nasional Persiapan MEA 2015, yang berfungsi merumuskan langkah antisipasi serta melakukan sosialisasi kepada masyarakat dan KUKM mengenai pemberlakuan MEA pada akhir 2015. Adapun langkah - langkah antisipasi yang telah disusun kementerian koperasi dan UKM untuk membantu pelaku KUKM terhadap MEA, peningkatan efisien produksi dan manajemen usaha, peningkatan daya serap pasar produk KUKM lokal, penciptaan iklim usaha yang kondusif. namun, salah satu faktor hambatan utama bagi sektor Koperasi dan UKM untuk bersaing dalam era pasar bebas adalah kualitas sumber daya manusia (SDM) pelaku KUKM yang secara umum masih rendah. Untuk meningkatkan kualitas pelaku KUKM, harus melaksanakan berbagai pembinaan dan pelatihan, baik yang bersifat teknis maupun manajerial. Namun, banyaknya tenaga kerja yang tidak terampil tentu berdampak pasda kualitas produk yang dihasilkan. Oleh karena itu, melakukan pembinaan dan pemberdayaan KUKM yang di arahkan pada peningkatan kualitas dan standar produk, agar mampu meningkatkan kinerja KUKM untuk menghasilkan produk - produk yang berdaya saing tinggi. sektor koperasi dan UKM yang paling penting untuk dikembangkan dalam menghadapi MEA 2015 itu yang terkait dengan industry kreatif dan inovatif, handicraft, home industry, dan teknologi informasi, juga berupaya meningkatkan akses dan transfer teknologi untuk mengembangkan pelaku UKM inovatif sehingga nantinya mampu bersaing dengan pelaku UKM asing. peningkatan daya saing dengan pemanfaatan teknologi informasi dan komunikasi (TIK), diperlukanpara pelaku UKM di Indonesia untuk menghadapi persaingan usaha yang makin ketat, khusunya dalam menghadapi MEA para pelaku UKM harus memanfaatkan teknologi selus - lusnya untuk mengembangkan usahanya sehingga mereka bisa cepat maju dan siap bersaing secara global.

Sebagai salah satu dari tiga pilar utama ASEAN Community 2015, ASEAN Economic Community yang dibentuk dengan misi menjadikan perekonomian di ASEAN menjadi 
lebih baik serta mampu bersaing dengan negara - negara yang perekonomiannya lebih maju dibandingkan dengan kondisi Negara ASEAN saat ini. Selain itu juga dengan terwujudnya ASEAN Community yang dimana di dalamnya terdapat AEC, dapat menjadikan posisi ASEAN menjadi lebih strategis di kancah internasional, kita mengharapkan dengan terwujudnya komunitas masyarakat ekonomi ASEAN ini dapat membuka mata semua pihak, sehingga terjadi suatu dialog antar sektor yang dimana nantinya juga saling melengkapi diantara para stakeholder sektor ekonomi di negara negara ASEAN ini sangat penting. Misalnya untuk infrastruktur, jika kita berbicara tentang infrastruktur mungkin Indonesia masih ingat dinilai kurang, baik itu berupa jalan raya, bandara,pelabuhan, dan lain sebagainya. Dalam hal ini kita dapat memperoleh manfaat dari saling tukar pengalaman dengan anggota ASEAN lainnya.jika di lihat dari sisi demografi sumber daya manusia- nya, Indonesia dalam menghadapi ASEAN Economic Community ini sebenarnya merupakan salah satu negara yang produktif. Jika dilihat dari faktor usia, sebagian besar penduduk Indonesia atau sekitar $70 \%$ nya merupakan usia produktif. jika kita lihat pada sisi ketenaga kerjaan kita memiliki 110 juta tenaga kerja (data BPS,tahun 2007), namun apakah sekarang ini kita utilize dengan tenaga kerja kita yang berjumlah sekitar 110 juta itu. Melihat kondisi ekonomi Indonesia yang stabil dan mengalami peningkatan yang signifikan dalam beberapa tahun belakangan ini, saya menyimpulkan bahwa mengenai kesiapan Indonesia dalam menyongsong ASEAN Economic Comminity, bisa dikatakan siap, dapat dilihat dari keseriusan pemerintah dalam menangani berbagai masalah dalam bidang ekonomi baik itu masalah dalam negeri maupun luar negeri.

Selain itu, polisi Indonesia sebagai Chair dalam ASEAN berdampampak sangat baik untuk menyongsong terealisasinya ASEAN Economic Community. Dari dalam negeri sendiri Indonesia telah berusaha untuk mengurangi kesenjangan ekonomi kesenjangan antara pemerintah pusat dengan daerah lalu mengurangi kesenjangan antara peng- usaha besar dengan UKM dan peningkatan dalam beberapa sektor yang mungkin masih harus didorong untuk meningkatkan daya saing.

Sisa krisis ekonomi 1998 yang belum juga hilang dari bumi pertiwi, masih berdampak rendah pertumbuhan investasi baru (khususnya arus Foreign Direct Investment) atau semakin merosotnya kepercayaan dunia usaha, yang pada gilirannya menghambat pertumbuhan ekonomi nasional. Hal tersebut karena buruknya infrastruktur ekonomi,instabilitas makro - ekonomi, ketidaakpastian hukum dan kebijakan, ekonomi biaya tinggi dan lain lain. Pemerintah tidak bisa menunda lagi untuk segera berbenah diri, jika tidak ingin menjadi sekedar pelengkap di AEC 2015. Keberhasilan tersebut harus didukung oleh komponen - komponen lain di dalam negeri. Masyarakat bisnis Indonesia diharapkan mengikuti gerak dan irama kegiatan diplomasi dan memanfaatkan peluang yang sudah terbentuk ini. Diplomasi Indonesia tidak mungkin harus menunggu kesiapan di dalam negeri. Peluang yang sudah terbuka ini, kalu tidak segera dimanfaatkan, kita akan tetinggal, karena proses ini juga diikuti gerak negara lain dan hal itu terus bergulir. Kita harus segera berbenah diri untuk menyiapakan sumber daya manusia yang kompetitif dan berkualitas global. Menuju tahun 2015 tidaklah lama, sudah siapkah kita akan tantangan dan peluang bagi kalangan profesional muda kita / mahasiswa untuk tidak berbengong- bengong menyaksikan lalu - lalang tenaga asing di wilayah kita? Tantangan Indonesia kedepan adalah mewujudkan perubahan yang berarti bagi kehidupan keseharian masyarakatnya. Semoga seluruh masyarakat Indonesia kita ini bisa membantu untuk mewujudkan kehidupan ekonomi dan sosial yang layak agar kita bisa segera mewujudkan masyarakat ekonomi ASEAN tahun 2015.

Menurut Michael porter, ada tiga landasan strategis yang dapat membantu organisasi memperoleh keunggulan kompetitif, yaitu keunggulan biaya, diferensiasi,dan focus. Porter menamakan ketiganya strategis umum (strategis generic). Keunggulan biaya mene- 
kankan pada pembuatan produk standar dengan biaya per unit sangat rendah untuk konsumen yang peka terhadap peruabhan harga. Diferensiasi adalah strategis dengan tujuan membuat produk yang menyediakan jaa yang dianggap unik diseluruh industry dan ditujukan kepada konsumen yang tidak terlalu peduli dengan perubahan harga. Fokus berarti membuat produk dan menyediakan jasa yang yang memenuhi keperluan sejumlah kelompok kecil konsumen.

Strategis porter mensyratkan adanya penataan organisasi, prosedur pengendalian, system intensif yang berbeda. Perusahaan besar dengan akses sumber daya yang besar biasanya bersaing dengan landasan keunggulan biaya dan atau dengan diferensiasi, sedangkan perusahaan kecil sereing bersaing dengan landasan focus.

Porter menekankan pentingnya perencana strategis melakukan analisis biaya manfaat untuk mengevaluasi berbagai peluang diantara unit - unit bisnis yang sudah ada dan unit bisnis yang potensial dalam perusahaan. Berbagai aktivitas dan sumber daya dapat meningkatkan keunggulan kompetitif karena dengan demikian biaya berkurang dan diferensiasi meningkat. Selain itu, porter juga menekankan perlunya perusahaan mengalihkan keterampilan dan keahlian diantara unit bisnis otonomi secara efektif agar memeroleh keunggulan kompetitif.

\section{LANDASAN STRATEGIS GENERIK}

Berdasarkan analisis kompetitif, porter menyatakan bahwa walupun suatu perusahaan memiliki banyak kekuatan dan kelemahan dalam berhadapan para pesaing. Terdapat dua jenis dasar keunggulan kompetitif yang di miliki oleh suatu perusahaan yaitu biaya rendah deferensiasi yang sangat ditentukan oleh struktur industri. Keduanya dihasilskan dari kemampuan perusahaan dalam menanggulangi kelima kekuatan dengan lebih baik dibandingkan pesaingnya. Untuk kepentingan inilah maka porter menyarankan tiga strategis yang harus dipertimbangkan oleh perusahaan yaitu strategis keunggulan biaya (overall cost leadership), diferensiasi (differentiation), dan focus (focus) biaya dan focus diferensiasi. a. Keunggulan Biaya (Overal Cost Leadership).

Keunggulan biaya merupakan strategis yang paling jelas dari ketiga generic. Dengan konsep ini, perusahaan bersiap menjadi produsen berbiaya rendah di dalam industrinya. Sumber keunggulan biaya bervariasi dan bergantung pada struktur industry. Produsen berbiaya rendah harus menemukan dan mengeksploitasi semua sumber keunggulan biaya, mka perusahaan akan menjadi perusahaan berkinerja tinggi di dalam industrunya asalakana perusahaan dapat menguasai harga pada rata - rata industry.

Strategis keunggulan biaya yang sukses biasanya mewarnai seluruh hal dalam perusahaan, terbukti dari efesiensi yang tinggi, biaya overhead yang rendah, kebocoran yang kecil tidak toleran pembocoranb, penyaringan ketat terhadap perminmtaan anggaran,rentang kembali yang lebar, penghargaan dikaitkan dengan penguranagan biaya, dan partisipasi karyawan yang luas dalam usaha pengendalian biaya.

b. Diferensiasi (differentiation)

Dalam strategi deferensiasi, perusahaan berusha menjadi unik dalam industrinya pada berbagai dimensi yang secaqra umum dihargai oleh pembeli. Cara melakukan diferensiasi berbeda untuk setiap industry. Deferensiai dapat didasarkan pada produk itu sendiri. Sistrem penyerahan produk yang dipergunakan unyuk menjualnya, pendekatan pemasaran, dan faktor lain. Perusahaan yang dapat mencapai dan mempertahankan dideferensiasi akan menjadi perusahaan berkinerja tinggi dalam insudrinya. Logika dari strategi diferensiasi mengharuskan perusahaan memilih atribut untuk mendiferensiasikan diri secara berbea dengan atribut pesaing.

Strategi diferensiasi yang berhasil memungkinkan perusahaan menetapkan harga lebih tinggi untuk produknya yang memperoleh loyalitas pelanggan karena konsumen bisa begitu terikata dengan fitur - fitur diferensiasi. Fitur - fitur yang membedakan 
produk suatu perusahaan bisa mencakup pelayanan yang sangat unggul, ketersediaan suku cadang, dsai teknis,kinerja produk, umur manfaat produk, hermat bahan bakar, atau kemudahan penggunaan.

c. Focus (focus)

Focus berbeda dengan strategi lain karena menekan pilihan akan cakupan bersaing yang sempit dalam suatu industry. Dengan mengoptimalkan strategi untuk segmen pasar, penganut strategi fokus berusaha untuk mencapai keunggulan bersaing di dalam segmen sasaran walaupun tidak memiliki keunggulan bersaing secara keseluruhan. Strategi focus memiliki dua varian, dalam fokus biaya,perusahaan mengusahakan keunggulan biaya dalam se3gmen sasarannya, sedangkan dalam focus diferensiasi, perusahaan mengusahakan diferensiasi dalam segmen sasarannya. Apabila perusahaan dalam mencapai keunggulan biaya yang dapat dipertahankan (fokus biaya) atau diferensiasi (fokus diferensiasi) dalam segmennya dan segmen tersebut menarik scara struktural, maka penganut strategi fokus akan menjadi perusahaan yang berkinerja tinggi di dalam industrinya.

Strategi fokus akan sanagt efektif ketika konsumen mempunyai pilihan persyaratan tertentu yang dapat dipenuhi oleh perusahaan dan ketika perusahaan pesaing tidak berusaha untuk melakukan spesialisasi dalam segmen konsumen yang sama. Strategi bersaing menurut porter adalah "Dijalankannya aksi menyerang atau bertahan oleh sebuah perusahaan di industrinya sehingga tercipta suatu posisi yang mampuu dipertahankan terhadap lima kekuatan bersaing, dengan posisi mana dihasilakan tingkay laba yang jauah di ats para pesaingnya". Tersedianya alat dan cara yang berdasarkan pendekatan ilmiah ilmu ekonomi industry membangkitkan kegairahan pihak - pihak di luar perusahaan. Kalangan terdiodik khususnya akademis dan konsultan kini berkempatan menunjukan kemampuan mereka menganalisis industri dan menawarkan resep strategi bersaing ke perusahaan - perusahaan

\section{TINJAUAN PUSTAKA \\ Strategi}

Menurut Michael porter (1985) < strategi adalah alat untuk mencapai keunggulan bersaing. Sedangkan menurut Chandler (1962), strategi adalah alat untuk mencapai tujuan perusahaan. Kemudian menurut Hamel dan Prahalad (1995), strategi adalah tindakan incremental dan berkesinambungan yang dilakukan berdarkan sudut pandang tentang apa yang diharapkan oleh pelanggan di massa depan, (Freddy, 3-4). dari berbagai strategi di atas bisa ditaarik kesimpulan bahwa strategi adalah serangkaian keputusan dan aksi yang diimplementasikan dalam rangka memenangkan persaingan untuk mencapai tujuan perusahaan.

\section{Manajemen strategis}

Seperti halnya pemesaran, keuangan dan kegiatan-kegiatan lain dalam sebuh bisnis atau perusahaan strategi juga memperlukan penerapan ilmuan manajemen didalamnya, yang dinamakan manajemen strategi. Manajemen strategi adalah seni pengetahuan untuk meluruskan, mengimplementasikan dan mengevaluasi keputusan litas fungsional yang membuat organisasi mampu mencapai obyektifinyan, (Freedy, 5).

Manajemen strategi adalah sejumlah keputusan dan tindakan yang mengarah pada penuyusan suatu srategi atau sejumlah srtategi yang evektif yang efektif untuk membantu mencapai sasaran perusahaan,(Lawrence $R$ Jauch dan William F Glueck, 6). Berdarkan definisi-definsi diatas, bisa disimpulkan, manajemen strategi adalah suatu rangkaian tindakan yang dilakukan manajemen puncak sebagai pembuat keputusan bagi perusahaan. Untuk mencapai tujuan utama perusahaan dengan cara melakukan tahapan-tahapan tindakan seperti formulasi, implementasi dan evaluasi strategi.

\section{Jenis-jenis strategi}

a. Forward integration:

Mendapatkan kepemilikan atau meningkatkan kendali atas atau pengecar 
b. Backward integaration:

Mendapatkan kepemilikan atau meningkatkan kendali atas penyuplai.

c. Horizontal integration

Mendapatkan pemilikan atau meningkatkan kendali atas pesaing.

d. Market penetration:

Mengapa peningkatan pangsa atas barang atau jasa yang ada, dalam pasar yang telah ada melakukan usaha pemasaran.

e. Market Development:

Memperkenalkan barang atau jasa yang telah ada pda area geografik baru.

f. Product Develpoment:

Mencari peningkatan penjualan dengan improvisasi pada barang atau jasa atau membuat barang baru.

g. Cencentric Deversification:

Menambah yang baru, namunj berhubungan atas barang atau jasa yang sudh ada.

h. Conglomerate Diversification:

Menambah yang baru, namun atas barang atau jasa yang tidak berhubungan.

i. Horizontal Diversification:

Menambah yang baru, tidak berhubungan dengan barang atau jasa yang ada, namun ditujukan bagi konsumen yang ada sekarang.

j. Joint Venture:

Dua atau lebih perusahaan sponsor membentuk sebuah organisasi terpisah bagi kegunaan perusahaan.

k. Retrenchment:

Pengelompokan ulang mealaui pengurangan biaya dan asset dalam mengantisipasi turunya penjualan dan laba.

1. Divesture:

Menjual sebuah divisi atau bagian dari sebuah organisasi.

m. Liquidation:

\section{Strategi Generik Michael Porter}

Strategi bersaing mempunyai tujuan menegakkan posisi yang menguntungkan, (porter,1) strategi bersaing generic adalah pendekatan yang dilakukan untuk mengungguli pesaing pesaingnya dalam industri, dimna dalam struktur industry tertentu berarti perusahaan dapat memperoleh tingkat pengembalian yang tinggi sementara di lain pihak keberhasilan dalam salah satu dari strategi generik perlu dilakukan peningkatan untuk memperoleh penerimaan yang lkayak dalam situasi tertentu, (porter,31) > strategi jangka panjang seharusnya diperoleh dari suatu usaha perusahaan untuk mencari keunggulan bersaing bersadarkan salah satu dari ketiga strategi generic. Strategi generic tersebut adalah:

a. Strategi Keunggulan Biaya Menyeluruh Untuk mendapatkan keunggulan biaya diperlukan konstruksi agresif dari fasilitas yang efisien serta usaha yang giat untuk mencapai penurunan biaya yang disebabkan oleh pengalaman pengendalian biaya dan overhead yang ketat serta meminimalkan biaya - biaya dalam bidang litbang. Pelayanan, armada penjualan, periklan dan lain - lain. Biaya yang relatif lebih rendah dari pesaingnya akan menjadi faktor utama yang menjiwai keseluruhan strategi pemasaran,meskipun mutu pelayanan dan bidang -bidang jasa yang lainnya tidak dapat diabaikan.

Porter berpendapat bahwa dengan memiliki biaya rendah akan membantu perusahaan mendapatkan laba di atas rata rata dan memberikan perusahaan tersebut ketahanan terhadap sivilitas dari para pesaing karna biaya yang lebih rendah memungkinkan perusahaan untuk tetap mendapatkan laba setelah para pesaingnya mengorbankan laba mereka dari pesaingan. Posisi biaya yang lebih rendah biasa nya menempatkan perusahaan pada posisi yang menguntungkan dalam menghadapi produk atau jasa pengganti, sehingga posisi biaya rendah dapat melindungi perusahaan dari lima kekuatan persaingan karena kekuatan tawar menawar hanya akan terus mengikis laba sampai para pesaing mengalah. Investasi seperti ini merupakan prasyarat untuk mempertahankan posisi biaya rendah, (porter,33).

b. Strategi diferensiasi

Strategi ini adalah strategi untuk mendiferensiasikan produk atau jasa yang ditawarkan perusahaan dengan menciptakan suatu produk atau jasa baru 
yang dirasakan oleh seluruh industri sebagai sesuatu yang unik. Pendekatan ini bukan hanya untuk meningkatkan mutu fisik dari produk atau jasa saja, tetapi juga dapat menciptakan nilai tertentu bagi pembeli.strategi ini merupakan strategi yang baik untuk menghasilkan keuntungan di atas rata - rata dalam suatu industri, karena strategi ini menciptakan posisi yang aman untuk lima kekuatan persaingan meskipun caranya berbeda dengan strategi keunggalan biaya menyelurah penggunaan strategi ini bukan berarti bahwa perusahaan mengabaikan faktor biaya, tetapi biaya bukanlah target utama. Diferensiasi terkadang akan menghambat pencapaian tujuan untuk memperoleh bagian pasar yang tinggi, karena hal ini dapat mengakibatkan produk yang dihasilkan ekslusif dan tidak semua pelanggan mampu atau mau membayar dengan harga yang lebih tinggi.

c. Strategi fokus

Strategi generik yang terakhir adalah fokus, memusatkan pada kelompok pembeli,segmen lini produk,atau pasar geografis tertentu jika strategi biaya rendah dan diferensiasi ditujukan untuk mencapai sasaran mereka dikeseluruhan indistri,maka strategi fokus dibangun untuk melayani target tertentu secara baik.

Strategi ini di dasarkan pada pemikiran bahwa perusahaan dengan demikian akan mampu melayani target strateginya yang sempit secara lebih efektif dan efesien ketimbang pesaing dan pesaing yang lebih luas. Sebagai akibatnya,perusahaan akan mencapai diferesiasi karena mampu memenuhi kebutuhan target tertentu dengan lebih baik atau mencapai biaya yang lebih rendah dalam melayani target ini atau bahkan mencapai kedua - duanya. Meskipun strategi fokus untuk tidak mencapai biaya rendah atau diferensiasi dari segi pandang pasar sebagai keseluruhan strategi ini,sesungguhnya mencapai salah satu atau kedua posisi tersebut ditarget pasarnya yang lebih sempit (porter,35).
Ketiga strategi generik di atas merupakan pendekatan alternatif yang dapat digunakan untuk menanggulangi kekuatan -kekuatan persaingan. Perusahaan harus mengambil langkah - langkah untuk mencapai keunggulan biaya, mengarahkan dirinya pada target tertentu (fokus) atau mencapai kekhasan tertentu (diferensiasi).

\section{Tahapan Manajemen Strategi}

Proses manajemen strategi terdiri dari tiga tahap: perumusan strategi, implementasi strategi, dan evaluasi strategi.

a. Perumusan Strategi

Keputusan perumusan strategi mengikat suatau organisasi pada produk, pasar,sumber daya, dan teknologi spesifik selama periode waktu tertentu. Perumusan strategi termasuk memutuskan bisnis baru apa yang perlu dimasuki, bisnis apa yang harus dihentikan, bagaimana mengalokasikan sumberdaya, apakah memperluas operasi atau versifikasi, apakah akan memasuki pasar internasional, apakah akan melakukan merjer atau membentuk usaha patungan, dan bagaimana menghindari pengambilalihan perusahaan pesaing, (freddy, 15).

b. Implementasi Strategi

Implementasi strategi sering di sebut juga tahap melakukan tindakan dalam manjemen strategi. Melakukan implementasi berarti, mengarahkan atau menggerakan manajer manajer dan karywan -karyawan untuk menerapakan strategi yang telah diinformasikan kedalam sebuah tindakan nyata. Strategi implementasi memiliki tiga tindakan dasar yaitu: membuat tujuan tahunan, membuat kebijakan dan mengalokasikan sumber daya,(fredy,15).

c. Evaluasi Strategi

Tahap terakhir di manajemen strategi adalah evaluasi strategi. strategi - strategi dapat dimodofikasi di masa yang akan dating,sebab faktor eksternal da internal selalu berubah.Di dalam evaluasi strategi terdapat tiga tindakan dasar yaitu: melihat kembali faktor - faktor internal dan eksternal untuk dasar penerapan strategi 
saat ini, mengukur kinerja perusahaan mengambil tindakan pengkoreksian. evaluasi strategi di butuhkan karena, keberhasilan saat ini adalah bukan merupakan jaminan untuk berhasil di hari esok,(freddy 15).

\section{Lingkungan Industri}

a. Perseteruan perusahaan yang bersaing. Cenderung meningkat kalo jumlah pesaing bertamabh, kareana perusahaan yang bersaing menjadi setra dalam ukuran dan kemampuan, karena permintaan produk industry menurun, dan arena potongan harga menjadi biasa. Strategi yang di jalankan oleh salah satu perusahaan dapat berhasil hanya sejauh bahwa strategi itu menyediakan keunggulan bersaing atas yang dijalankan oleh perusahaan pesaing, (freddy,130).

b. Ancaman masuknya pesaing baru. Perusahaan baru datang kadang - kadang masuk ke dalam industri dengan produk yang lebih tinggi,harga yang lebih rendah dan sumber pemasaran yang luar biasa. Hamabatan untuk masuk dapat termasuk keperluan untuk memperoleh skala ekonomi dengan cepat, keperluan pelanggan yang kuat,pilihan mereka yang kuat, persyratan modal yang besar, kurangnya saluran distribusi yang memadai, kebijkan peraturan pemerintah,tariff,kurangnya akses ke bhan baku, kepemilikan paten, lokasi yang tidak menguntungkan, serangan balik oleh perusahaan yang bertahan, dan kejenuhan potensial pasar, (freddy,130).

c. Ancaman potensial produk substitusi. Produk pengganti menempatkan batas dari harga yang dapat ditetapkan sebelum konsumen akan peindah ke produk pengganti. Kekuatan persaingan dari produk pengganti paling baik di ukur dengan pangsa pasar yang direbut oleh produk tersebut, di samping rencana perusahaan itu yang meningkatkan kapsitas dan penetrasi pasar, (freddy, 130).

d. Kekuatan menawarkan dari pemasok. demi kepentingan pemasok dan produsen untuk saling membantu dengan harga yang wajar, mutu yang diperbaiki, pengembangan pelayanan batu, penyerahan barang, tepat waktu dan mengurangi biaya persediaan jadi meningkatkan kemampuan meraih laba jangka panjang bagi semua pihak yang terkait. perusahaan biasanya dapat melakukan negosiai persyaratan yang lebih baik menguntungkan dengan pemasok kalau integrasi ke belakang strategi merupakan strategi merupakan strategi yang banyak dipakai diantara perusahaan pesaing dalam industry, (freddy,130)

e. Kekuatan menawar dari konsumen. Kekuatan menawar juga lebih besar kalu produk yang di beli standar atau tidak berbeda. perusahaan pesaing mungkin menawarkan garansi lebih panjang atau pelayan khusus untuk memperoleh loyalitas pelangan lalu kekuatan menawar dari konsumen luar biasa. Konsumen sering dapat melakukan negosiasi harga jual, jaminan, dan asesoric kemasan sampai tingkat tetentu, (freddy,131).

\section{TUJUAN DAN MANFAAT PENELITIAN Tujuan}

Tujuan dari penelitian ini adalah untuk menguji hubungan antara strategi generik dan kinerja perusahaan dan untuk mengetahiu penerapan strategi generik porter dalam menjelaskan perbedaan pengaruhnya terhadap kinerja perusahaan.Dalam penelitian ini terdapat tiga variable independen yang dianalisis, yaitu: strategi diferensiasi, kepemimpinana biaya, dan strategi terpadu. Sementara variable dependennya adalah kinerja perusahaan yang merupakan ukuran subjektif dari pemenuhan tujuan fari kinerja relative peasing. Dta yang telah terkumpul selanjutnya dianalisis dengan menggunakan analisis regresi linier berganda. hasil penelitian ini menunjukan bahwa penerapan strategi generic berpengaruh penting terhadap kinerja perusahaan, sedangkan pemilihan strategi diferensiasi lebih baik pengaruhnya pada kinerja perusahaan di bandingkan dengan strategi kepemimpinan biaya, maupun strategi terpadu. 


\section{Manfaat Penelitian}

Manfaat yang diharapkan dari penelitian ini adalah untuk menambah wawasan dan pengetahuan dalam analisis dan aplikasi manajemen strategi pada sebuah perusahaan, dan hasil penelitian ini dapat di jadikan masukan bagi usaha kecil sepatu untuk meningkatkan daya saingnya.

\section{METODE PENELITIA \\ Metode Penelitian}

Penelitian ini menggunakan pendekatan kuantitatif, karena menekankan ada pengujian teori - teori melalui pengukuran variabel - variable penelitian dengan angka dan melakukan analisis data dengan prosedur ststistik. penelitian ini menggunakan jenis penelitian survey. sedangkan penelitian ini dilakukan dengan mkasud explanatory penelitian ini bertujuan untuk mengetahui hubungan antra strtegi generic dan kinerja perusahaan dan untuk menguji penerapan strtegi porter dan menjelasjkan perbedaan pengaruhnya terhadap kinerja perusahaan.

\section{Metode Pengumpulan Data}

Penulisan menggunakan pengumpulan data

1. Riset ke pustakaan (Library Research)

Yaitu pengumpulan data melalui literatur literatur atau kepustakaan serta membaca dan mempelajari buku - buku yang ada hubungannya dengan permasalahan yang sedang dibahas, sehingga akan diperoleh berbagai informasi yang akan di pakai sebagai dasar untuk pembahasan penelitian ini.

2. Riset Lapangan (Field Research)

Yaitu melakukan pengamatan langsung ke perusahaan yang di jadikan objek penelitian dengan cara melakukan wawancara dengan pihak yang berkepentingan pada perusahaan yang diteliti.

3. Kuesioner (Angket)

Merupaka teknik pengumpulan data yang di lakukan dengan cara menyebar kuesioner berisi beberapa pertanyaan teknik sampling yang digunkan adalah purposive sampling yaitu teknik penentuan sampel dengan pertimbangan tertentu (Sugiono, 78).

\section{Metode Analisis Data}

Metode analisa yang digunkan adalah:

Analisis Lingkungan persaingan industri perusahaan ada 5 jenis, yaitu:

a. Entri potensial dari pesaing baru (Masuknya pesaing baru):

1) Skala ekonomi

2) Pengenalan merek

3) Kemungkinan masuk ke jalur distribusi

4) Kebutuhan modal

5) Mudah tidaknya masuk ke teknologo modern

6) Mudah tidaknya masuk ke sumber bahan baku

7) Kurva pengalaman

b. Perseteruan diantara perusahaan yang bersaing:

1) Jumlah pesaing yang deakt

2) Pertumbuhan industry relatif

3) Pilihan - pilihan produk

4) Pertumbuhan kapsitas produksi

5) Keanekaragaman pesaing

\section{c. Kekuatan menawar dari konsumen}

1) Jumlah pemebeli utama

2) Ketersediaan produk subtitusi

3) Biaya bagi pembeli

4) Ancaman pembeli langsung ke pemasok

5) Ancaman industri langsung ke distributor

6) Pembeli memberikan profit

\section{d. Kekuatan menawar dari pemasok}

1) Jumlah pemasok penting

2) Ketersediaan pengganti produk penyalur

3) Ancaman supplier langsung ke konsumen

4) Ancaman industry langsung ke sumber bahan baku

5) Kontribusi penyalur kepada pelayanan

\section{e. Potensial ancaman produk pengganti}

1) ketersediaan produk pengganti

2) Biaya beralih bagi pemakai

3) Agressivitas dan profitabilitas produk subtitusi

4) Harga dan nilai produk subtitusi 
Mencocok karakteristik operasi perusahaan dengan model strategi generik Michael porter Karakteristik perusahaan yang sesuai dengan masing - masing strategi

a. Overall low cost leadership strategies

b. Strategi bersaing dengan menjadi harga produk termurah.

c. Differentiation strategies

d. Strategi dengan menawarkan diferensiasi produk dan atribut yang unik untuk memenangkan persaingan serta meraih profit yang lebih besar.

e. Fokus strategies

f. Strategi yang mengkhususkan dir melayani suatu pasar atau segmen tertentu yang lebih fokus yang cenderung yang tidak di layani dengan baik oleh pesaing utama.

\section{Populasi dan sampel}

Populasi dan sampel dalam penelitian ini adalah usaha kecil sepatu yang berada pada kelurahaan cipayung ciputat tanggerang selatan.

\section{HASIL DAN PEMBAHASAN \\ Hasil}

Berdasarkan uji statistic menjelaskan baha variabel diferensiasi, kepemimpinan biaya, fokus, kinerja perusahaan, yang masing masing terdiri dari 5 butir pertanyaan yang keseluruhannya menunjukan valid dengan nilai signifikasi lebih kecil dari 0,05 . Hal ini berarti bahwa semua item pertanyaan yang digunakaan dalam penelitian itu mampu mengungkapkan sesuatu yang diukur pada kuesioner tersebut.

Uji reliabilitas adalah mengukur suatu kuesioner yang merupakan indicator variabel atau konstruk. Suatu kuesioner dikatakan reliable atau handal jika jawaban seseorang terhadap pertanyaan addalah konsisten atau stabil dari waktu ke waktu. Suatu konstruk atau variabel dikatakan reliable jika memberikan nilai cronbach alpha $>0,60$.

Berdasarkan uji reliabilitas diperoleh kesimpulan bahwa konstruk pertanyaan dari variabel X1 (Diferensiasi) dikatakan reliable, karena nilai cronbach's alpha 0,758 >0,60. Hasil uji relibilitas data dari hasil variabelo X2 (kesimpulan biaya), dikatakan reliable karena nilai cronbach 's alpha $0,753>0,60$. Pada uji reliabilitas variablbe Y (kinerja perusahaan) disimpulkan bahwa konstruk pertanyaan dikatakan reliable karena nilai cronbach's alpha $0,750>0,60$.

Nilai koefisien regresi dalam analisis regresi linier berganda, dapat diinterprestasikana sebagai berikut:

a. Konstanta sebesar 1.971 skor, berarti jika diferensiasi (X1),Kepemimpinan Biaya (X2) dan Fokus (X3) nilainya adalah 0, maka kinerja perusahaan (Y) adalah 1.971 skor atau dapat dikatakan adanya kinerja perusahaan yang tinggi.

b. Variable diferensiasi (X1) yang memiliki koefisien regresi sebesar 0,347 skor, artinya jika variable kepemimpinan biaya (X2) dan fokus (X3) bernilai tetap, sedangkan variable diferensiasi (X1) mengalami kenaikan 1 skor, maka kinerja perusahaan (Y) akan mnengalami kenssaikan sebesar 0,347 skor. Maka koefisiennya bernilai positif yang berartui terjadi hubungan positif antara diferensiasi dengan kinerja perusahaan, semakin besar diferensiasi makan kinerja perusahaan semakin tinggi.

c. Variable kepemimpinan biaya (X2) yang memiliki koefisien regresi sebesar 0,221 skor, artinya jika variablere independen lain yaitu diferensiasi (X1), Fokus (X3) bernilai tetap, sedangkan variable kepemimpinan biaya (X2) mengalami kenikan 1 skor, maka akan terjadi peningkatan terhadap kinerja perusahaan (Y) sebesar 0,221 skor. koefisiennya bernilai positif yang berarti terjadi hubungan positif antara kepemimpinan biaya dengan kinerja perusahaan, semakin besar kepemimpinan biaya maka semakin tinggi kinerja perusahaan.

d. Variable fokus (X3) yang memiliki koefisien regresi sebesar 0,343 skor, artinya jika variable independen lain yaitu diferensiasi (X1) dan kepemimpinan biaya (X2) bernilai tetap, sedangkan variable fokus (X3) mengalami kenikan 1 skor, maka akan terjadi peningkatan terhadap kinerja perusahaan (y) sebesar 0,343 skor. Maka koefisiennya bernili positif yang berarti terjadi 
hubunganb positif antara fokus dengan kinerja perusahaan,semakin tinggi fokus maka akan semakin tinggi kinerja perushaan.

Hasil uji t hipotesis dalam penelitian ini, memperlihatkan uji t untuk variable diferensiasi (X1) menghasilkan t-hitung sebesar 17,691 dengan tingkat signifikan sebesar $0,000<0,05$, maka Ho ditolak, artinya bahwa diferensiasi secara parsial berpengaruh terhadap kinerja perusahaan. nilai t-hitung positif, artinya pengaruh yang terjadi adalah positif, semakin tinggi diferensiasi, maka semakin besar kinerja perusahaan. untuk variable kepemimpinan biaya, (X2) menghasilkan thitung sebesar 11,157 dengan tingkat signifykan sebesar 0,000 $<0,05$, maka Ho ditolak, artinya bahwa kepemimpinan biaya secara parsial berpengaruh terhadap kinerja perusahaan. Nilai $\mathrm{t}$ - hitung positif, artinya pengaruh yang terjadi adalah positif, semakin tinggi kepemimpinan biaya maka semakin besar kinerja perusahaan. untuk variable fokus (X3) menghasilkan t-hitung sebesar 16, 958 dengan tingkat signifikan sebesar $0,000<0,05$, maka Ho ditolak, artinya bahwa fokus parsial berpengaruh terhadap kinerja perusahaan. nilai $t$ hitung positif, artinya pengaruh yang terjadi adalah positif, semakin tinggi fokus maka semakin besar kinerja perusahaan.

Hasil uji statistic F atau uji Anova/F test ini digunakan untuk menguji ada tidaknya pengaruh variable independen diferensiasi (X1), kepemimpinan biaya (X2) Fokus (X3), semakin simultan terhadap variabledependen kinerja perusahaan (Y). Output SPSS menunjukan diperolehnya nilai $\mathrm{F}$ adalah 1032.091 dan tingkat signifikan $0,000<0,05$, maka Ho ditolak yang berarti bahwa variable diferensiasi (X1), kepemimpinan biaya (X2), Fokus, (X3) secara bersama - sama berpengaruh sangat signifikan terhadap kinerja perusahaan (Y).

Koefisien korelasi parsial (r) antara $\mathrm{Y}$ dan X1 dengan asumsi X2, dan X3 konstan adalah 0,682 dengan signifikan 0,000 $<0,05$, hal ini berarti bahwa terdapat hubungan secara signifikan anmtara diferensiasi dengan kinerja perusahan. korelasi kepemimpinan biaya dengan kinerja perusahaan, korelasi parsial antara $\mathrm{Y}$ dan X2 dengan X1 dan X3 konstan adalah 0,679 dengan signifikan 0,000 $<0,05$, hal ini berarti bahwa terdapat hubungan secara signifikan antara kepemimpinan biaya dengan kinerja perusahaan. Sedangkan korelasi parsial antara Y dan X3 dengan asumsi X1 dan X2 konstan adalah 0,691 dengan signifikan 0,000, 05, hal ini berarti bahwa terdapat hubungan secara signifikan anatara fokus dengan kinerja perusahaan.

Koefisien korelasi ganda (R), diperoleh angka $\mathrm{R}$ sebesar 0,788, hali ini menujukan bahwa korelasi antara variable dependen dengan ketiga variable independennya adalah kuat, artinya hubungan yang terjadi antra variable independen (Diferensiasi, kepemimpinan biaya dan fokus) dan variable dependennya (kinerja perusahaan) secara serentak adalah kuat dan searah.

Koefisien determinasi diperoleh nilai $\mathrm{R}$ square $=0,621$ hal ini menunjukan bahwa 0,621 atau $62,1 \%$ variable kinerja perusahaan dipengaruhi atau dijelaskan oleh variable dierensiasi, kepempinan biaya dan fokus atau variasi variable independen yang digunakan dalam model (Dierensiasi, Kepemimpinan biaya dan Fokus). mampu menjelaskan sebesar $62,1 \%$ variasi variable dependen (Kinerja Perusahaan). Sementara selebihnya 37,9\% dipengaruhi/dijelaskan oleh variable lainnya yang tidak dimasukkan dalam penelitian ini.

Analisis desrikptif Pengaruh Strategi Generik terhadap Kinerja Perusahaan, berdasarkan dari hasil analisis regresi dan analisis koefisien korelasi dapat disimpulkan bahwa Pengaruh Strategi Generik terhadap Kinerja perusahaan sangat tinggi. Hal ini terlihat dari faktor-faktor yang mempengaruhi Kinerja Perusahaan yaitu pertama, Diferensiasi yang mempunyai pengaruh dan hubungan yang di signifikan serta positif terhadap Kinerja Perusahaan Kedua, Kepemimpinan Biaya tidak mempunyai pengaruh dan hubungan yang signifikan serta posotif terhadap Kinerja Perusahaan. Ketiga, Fokus mempunyai pengaruh dan hubungan yang signifikan serta positif terhadap Kinerja Perusahaan. 


\section{Pembahasan}

Pengaruh strategi Diferensiasi terhadap Kinerja Perusahaan. Diferesiasi adalah strategi Generik yang menekankan pada keunggulan pada produk untuk menjaga loyalitas pelanggan. Dalam penelitian ini ada 6 indikator; 1 . (Pengembangan Produk Baru atau yang tersedia, 2) tingkat pengenalan produk baru ke pasaran, 3) penekanan jumlah produk baru yang ditawarkan, 4) intensitas iklan dan pemasaran, 5) penekanan pada pengembangan tenaga penjualan, 6) penekanan pada pembangunan merk yang kuat.

Hasil penelitian terhadap usaha kecil sepatu di cipayung menunjukan penerapan strategi diferensiasi berpengaruh penting terhadap Kinerja Perusahaan. Hasil penelitian ini mendukung penelitian sebelumnya yang dilakukan oleh O'Farrell (1992), Marlin dan Hoffman (1994), Kumar dan Strandholm (2002) serta Koo dan Nam (2004), bahwa strategi diferensiasi berpengaruh pada kinerja perusahaan. Jadi temuan hasil penelitian ini menunjukkan bahwa variable diferensiasi memiliki hubungan secara signifikan dengan variable kinerja perusahaan. Nilai rata-rata indikator diferensiasi terkecil adalah 3,805 sedangkan 5 indikator lainnya lainnya di atas 4 sehingga secara keseluruhan jawaban jawaban responden dinilai baik untuk seluruh indikator variable diferensiasi. Adapaun berdasarkan analisis faktor terhadap indikator strategi diferensiasi yang memiliki bobot tertinggi adalah indikator nomor 1 diikuti nomor 5,2,4,3 dan 6 sehingga dalam penerapan strategi diferensiasi indikator yang perlu mendapatkan perhatian adalah pengembangan pada produk baru atau produk yang tersedia, penekanan pada pengembangan tenaga penjualan dan tingkat pengenalan produk baru ke pasaran.

Pengaruh Strategi Kepemimpinan Biaya terhadap kinerja perusahaan, adalah stretegi generik yang menekankan pada usaha keras untuk mencapai penurunan biaya karna pengalaman, pengendalian dan overhead yang ketat serta meminimalkan biaya. Adapun indikator kepemimpinan biaya terdiri dari enam indikator yakni; a. efesiensi biaya produksi,

b. mencari cara mengurangi biaya

c. efesiensi operasional

d. mengoptimalkan kapasitas penjualan,

e. menawarkan harga kompetitif

f. pengendalian biaya umum.

Hasil penelitian terhadap usaha kecil sepatu cipayung menunjukkan penerapan strategi kepemimpinan biaya tidak berpengaruh signifikan terhdapa kinerja perusahaan.

Strategi fokus digunakan untuk membangun keunggulan bersaing dalam satu pasar yang paling sempit. Strategi ini ditunjukkan untuk melayani kebutuhan konsumen yang jumlahnya relatif kecil. Strategi ini akan lebih efektif jika konsumen membutuhkan suatu kekhasan tertentu yang tidak di minati oleh perusahaan pesaing. Ada dua fokus yaitu fokus biaya dam fokus diferensiasi, pada dasarnya merupakan pendapatan untuk menciptakan keunggulan. Fokus dan diferensiasi terdapat hubungan yang signifikan terhadap kinerja perusahaan.

\section{KESIMPULAN DAN SARAN \\ Kesimpulan}

Dari penelitian ini dapat di tarik kesimpulan bahwa penerapan strategi diferensiasi memiliki pengaruh yang penting terhadap Kinerja Perusahaan, terutama untuk indikator pengembangan produk baru atau yang sudah tersedia, pengembangan tenaga penjualan dan pengenalan produk baru ke pasar.

\section{Saran}

Berdasarkan hasil penelitian dan berbagai temuan yang telah disimpulkan, maka dapat dikemukakan saran sebagai berikut,pertama, diperlukan penelitian kepada industry lainnya untuk mengetahui pengaruh strategi generic sebagai perbandingan, kedua, para pemimpin perusahaan dalam penerapan strategi generic perlu menekankan pada strategi diferensiasi agar dapat bersaing dalam industry sepatu di Indonesia. 
DAFTAR PUSTAKA

Arthur A. Thompson,Jr, 1989,Economics of The Firm, Fifth Edision.

David, Fred R. 2004.Strategic Management: Concepts, Ninth Edition, PT. Indeks Kelompok Gramedia.

Lawenrence R. Jauch dan William F. Gulueck, 1988, Manajemen Strategi dan Kebijakan Perusahaan, Di Indonesia oleh Murad dan AR. Hary Sitanggang, Edisi ketiga,

Michael E. Porter, 1985, Strategi Bersaing, Di Indonesiakan oleh Agus Maulana, Edisi ketiga.

Purnomo,Setiawan Hari dan Zulkiflimansyah. 2007. Manajemen Strategi. Jakarta: Lembaga Penerbit Fakultas Ekonomi Universitas Indonesia.
Rangkuti, Freddy, 2004, Analisis SWOT: Teknik Membedah Kasus Bisnis, Gramedia Pustaka Utama, Jakarta.

Sugiono, 2001, Metodologi Penelitian Bisnis, Cetakan Ketiga, Alfabeta, Bandung.

http://www.bi.go.id/biweb/resources/gerai_inf o/index.html\#/Gerai\%20Info\%2028/0 http://www.jurnas.com/halaman/10/201 $1-11-19 / 189568$

http://isjd.pdii.lipi.go.id/admin/jurnal/1620827 39.pdf

http://www.antaranews.com/berita/436319/ kesiapan-koperasi-ukm-indonesiamenatap-era-mea-2015 